\title{
Analysis of Multi-attribute Utility Theory for College Ranking Decision Making
}

\author{
Adidtya Perdana \\ Universitas Harapan Medan \\ Medan, Indonesia \\ adid.dana@email.com
}

\author{
Arief Budiman \\ Universitas Harapan Medan \\ Medan, Indonesia \\ arief.diman13@email.com
}

Submitted: Oct 2, 2020

Accepted: Mar 17, 2020

Published: Apr 1, 2020

\begin{abstract}
Ranking of a tertiary institution, both state and private universities, can be the basis of the tertiary institutions of interest to prospective new students. The better the ranking of the college, the more popular the campus. In this study the author discusses the case of campus ranking in the city of Medan where the results to be received are the best campus decision making with the method used is the MAUT (Multi Attribute Utility Theory) method. The aim is to see what results can be given by using the MAUT method in determining the best campus in the city of Medan which results in ranking the campus in Medan. Does it provide optimal results or not. But every case that is solved using the methods in artificial intelligence, in this case the MAUT method is a method of the Decision Support System, certainly provides optimal results even though the results given are not complete or complete. Therefore, the writer has a vision going forward, conducting research in this field, especially for the case of campus ranking. In this study the variables used in determining campus ranking are Institutional, Student Activities, Lecturer HR, Research and Community Service, and Innovation. These five variables in the future can be added or subtracted as needed. The results obtained are optimal ranking results but are still limited to the reference model for internal institutions.
\end{abstract}

Keywords-Artificial Intelligence, Decision Support Systems, Multi Attribute Utility Theory (MAUT), Campus Ranking.

\section{INTRODUCTION}

Ranking of a tertiary institution, both state tertiary institution (PTN) and private tertiary institution (PTS) can be a reference for these tertiary institutions to attract prospective students. The higher the rank of a tertiary institution, the more popular the campus is for prospective students to enter. To determine the ranking of a campus or university a cluster mapping scheme is needed under the auspices of the Ministry of Research, Technology and Higher Education to improve the quality of universities on a regular and sustainable basis. Quoted from the page ristekdikti.go.id there are 5 assessment components that are the basis for ranking universities under the auspices of the Ministry of Research, Technology and Higher Education including Human Resources
Quality, Institutional Quality, Student Activity Quality, Research and Community Service Quality, and Innovation Quality (Kemenristekdikti, 2018).

In the HR quality assessment includes the percentage of the number of lecturers based on the level of graduates, S1, S2 or S3, the percentage of the number of lecturers based on their rank and functional position, and the ratio of the number of students to lecturers. For the Institutional Quality assessment includes the accreditation of institutions and study programs, the number of internationally accredited study programs, the number of foreign students and the number of university collaborations. In the assessment of Student Activities only cover student performance (Kemenristekdikti, 2018). 
At the fourth point, the evaluation of Research and Community Service Activities includes assessment of research performance, community service performance, and the number of scientific articles (journals and proceedings) published both locally, nationally, and internationally and not indexed or indexed (Scopus, Thomson Reuters, Copernicus, etc.) per number of lecturers. And the last assessment of Innovation Quality that includes innovation performance (Kemenristekdikti, 2018).

To be able to calculate in detail how the ranking of the campus is carried out, we need a method that can process well and can provide optimal results. For this reason, the writer uses the decision support system method which is a branch of artificial intelligence, namely the Multi Attribute Utility Theory method or abbreviated as MAUT. Where this method is a scheme whose final evaluation of an object is defined as the weight added by a value that is relevant to its dimension value. One of the strengths of this method is that it makes it possible to make direct comparisons of various sizes with the final ranking ranking of evaluations that reflect the choices of decision makers (Satria, Atina, Simbolon, \& Windarto, 2018).

From the research conducted by (Puspitasari, Rumita, \& Pratama, 2013) the MAUT model or method is used to compare business strategy priorities by looking at the aspects of infrastructure, time, cost, and business opinion in their research on the problem of choosing a business strategy center case study the earthenware industry Kasongan, Bantul, Yogyakarta. In this research the use of the MAUT method for decision making and the results provided by this method is the utility value of the most optimal strategies including management training, product development and entrepreneurs meeting.

In the research conducted by (Badrul, Rusdiansyah, \& Budihartanti, 2019) discussed the measurement of nutrition of children under five based on age, weight and height. Where the method used is Simple Additive Weighting (SAW) able to determine the nutritional status of toddlers by adding a toddler's body mass index variable so as to produce the right and valid decision using 20 toddler samples categorized by age group. In other research conducted by (Fajirwan, Arhami, \& Amalia, 2018) discusses ranking or ranking several criteria in deciding someone is entitled to receive assistance to renovate a house based on survey data conducted directly in the field. The use of the MAUT method in this study is to process data that is entered in the survey directly in the field using a computerized system that produces the final results through ranking. From the results of the rating, twofa houses will be selected that will receive renovation assistance based on the highest value with the highest value limit with a value limit of $\geq 0.58$. The boundary value $\geq 0.58$ is obtained from the results of discussions with the chairperson of Baitul Mal Aceh Barat Daya.

From the background explanation above, the writer raised the research theme of Analysis of Campus Ranking Results in Medan in Decision Making Using the Multi Attribute Utility Theory (MAUT) Method. It is expected that by using the MAUT method, in determining the ranking of campuses in the city of Medan will provide optimal results and in accordance with what is expected by the Kemenristekdikti cluster. And in the future the application made in the ranking of campuses in Medan using the MAUT method can be used by interested parties such as the Ministry of Research, Technology and Higher Education, as well as universities or campuses as a reference to improve the quality of each campus so that the rankings obtained can be ranked upgrading for the better.

\section{Literature REVIEW}

\subsection{Decision Support System}

The concept of Decision Support System (DSS) was first revealed in 1971 by Michael Scoot Morton with the term Management Decision System. Then a number of companies, research institutions and universities began to conduct research and build a Decision Support System, so that the resulting production can be concluded that this system is a computer-based system aimed at assisting decision making in utilizing certain data and models to solve various problems that unstructured (Latif, Jamil, \& Abbas, 2018).

Little defines Decision Support System as a computer-based information that produces a variety of alternative decisions to assist management in dealing with various structured and unstructured problems using data and models. From various definitions of a Decision Support System it can be concluded that a Decision Support System is a specific information system aimed at assisting management in making decisions relating to semistructured issues where no one knows for certain how decisions should be made (Windarto, 2017). This system has facilities to produce various alternatives that are interactively used by users (Latif et al., 2018). Decision support systems are composed by several components, namely the database, model base, and user interface (Imandasari \& Windarto, 2017).

\subsection{Multi Attribute Utility Theory Method}


Multi Attribute Utility Theory (MAUT) is a final evaluation scheme, $\mathrm{v}(\mathrm{x})$ of an object $\mathrm{x}$ is defined as a weight added by a value that is relevant to its dimension value. The phrase commonly used to refer to it is utility value. MAUT is used to convert several interests into numerical values on a scale from 0-1 with 0 representing the worst choice and 1 being the best. This allows direct comparisons of various sizes. The end result is a ranking order of evaluations that reflects the choices of decision makers. The whole evaluation value can be defined by the equation (Sadewo, Windarto, \& Hartama, 2017) (Satria et al., 2018):

$$
V(x)=\sum_{i=1}^{n} W j . X i j
$$

Where $\mathrm{V}(\mathrm{x})$ is the evaluation value of an object to $i$ and wi is the weight that determines the value of how important the element $\mathrm{i}$ to other elements. Whereas $\mathrm{n}$ is the number of elements. The total weighting is 1 . In summary the steps in the MAUT method are as follows (Sadewo et al., 2017) (Satria et al., 2018):

1. Break a decision into different dimensions.

2. Determine alternative weights in each dimension.

3. List all alternatives

4. Enter the utility for each alternative according to its attributes.

5. Multiply the utility by the weight to determine the value of each alternative.

Matrix Normalization:

$$
U_{(x)}=\frac{x-x i^{-}}{x i^{+}+x i^{-}}
$$

Information:

$\mathrm{U}_{(\mathrm{x})}$ : Normalization Alternative Weight $\mathrm{x}$

$\mathrm{x} \quad$ : Alternative Weight

$\mathrm{xi}^{-}$: The worst weight (minimum) of the $\mathrm{xth}$ criterion

$\mathrm{xi}^{+}$: The best weight (maximum) of the xth criterion

\section{Proposed Method}

\subsection{Research Subject}

The subjects in this study were campuses in the city of Medan to be ranked. The object of research is the ranking or ranking values of the campuses based on the criteria used. The variables used as rating criteria are:
1. HR Quality
2. Institutional Quality

3. Quality of Student Activities

4. Quality of Research and Community Service

5. Quality of Innovation

\subsection{Data Used}

In this study the data used to support the success of the study are as follows:

1. Campus or College Data in Medan City,

2. HR data such as the number of lecturers based on education and comparison of the percentage of the number of students.

3. Institutional Data such as Accreditation.

4. Student Activity Data owned by the college.

5. Research and Community Service Data based on cluster, and scientific publication data based on rank in Sinta2.

6. Innovation data owned by tertiary institutions is based on Ristekdikti innovation data.

For campus data used in this study using 10 campus data in the city of Medan. But to maintain the code of ethics, the names of the campuses are disguised using alphabetical order. So the campus data used are campus A, B, C, D, E, F, G, H, I, and J.

\subsection{Analysis of Method Implementation}

This section will explain how the Multi Attribute Utility Theory (MAUT) method is applied to this problem.

1. The first stage determines the weight of each criterion in which the criteria used are:

a. $\mathrm{C} 1=\mathrm{HR}$ : Percentage of Lecturers and Students
a. $1: 15-1: 20 \quad: 4$
b. $1: 21-1: 25 \quad: 3$
c. $1: 26-1: 35: 2$
d. $<15$ or $>35 \quad: 1$

b. $\mathrm{C} 2=\mathrm{HR}$ : Lecturer with Bechelor Degree Education (Percentage)
a. $0 \%: 4$
b. $0.1 \%-0.99 \%: 3$
c. $1 \%-8 \% \quad: 2$
d. $>8 \% \quad: 1$

c. $\mathrm{C} 3=\mathrm{HR}$ : Lecturer with Magister Degree Education (Percentage)

a. $80 \%-100 \%: 4$ 

b. $60 \%-79.99 \%: 3$
c. $40 \%-59.99 \%: 2$
d. $0 \%-39.99 \% \quad: 1$

d. $\mathrm{C} 4=\mathrm{HR}$ : Lecturer with Doctoral Degree Education (Percentage)
a. $10 \%-15 \%$
$: 4$
b. $7 \%-9.99 \%$
$: 3$
c. $3 \%-6.99 \%$
$: 2$
d. $0 \%-2.99 \%$

e. $\mathrm{C} 5=$ Institutional: Accreditation
a. A
$: 4$
b. B
$: 3$
c. C
$: 2$
d. -
$: 1$

f. $\quad$ C6 $=$ Student Activities
a. $>3.00$
$: 4$
b. $\quad 1.00-2.99$
$: 3$
c. $0.1-0.99$
$: 2$
d. 0
$: 1$

g. $\quad$ C7 = RCS: Research
a. Mandiri
$: 4$
b. Utama
$: 3$
c. Madya
$: 2$
d. Binaan
$: 1$

h. $\mathrm{C} 8=\mathrm{RCS}$ : Community Services
a. Unggul :4
b. Sangat Bagus : 3
c. Memuaskan :2
d. Kurang Memuaskan : 1

i. $\quad$ C9 = RCS: Publication (Sinta Ratings)
a. $1-300$
$: 4$
b. $301-500$
$: 3$
c. $501-700$
$: 2$
d. $>701$
$: 1$

j. $\quad \mathrm{C} 10=$ Inovation (Number of Inovation)
a. $>13$
$: 4$
b. $8-12$
$: 3$
c. 4-7
$: 2$
d. $0-3$
$: 1$

2. The second stage determines the preference weights of each criterion, is:

a. $\mathrm{C} 1=\mathrm{HR}$ : Percentage of Lecturers and Students = 3

b. $\mathrm{C} 2=\mathrm{HR}$ : Lecturer with Bechelor Degree Education (Percentage) $=3$

c. $\mathrm{C} 3=$ HR: Lecturer with Magister Degree Education (Percentage) $=3$

d. $\mathrm{C} 4=\mathrm{HR}$ : Lecturer with Doctoral Degree Education (Percentage $)=3$

e. $\mathrm{C} 5=$ Institutional: Accreditation $=4$

f. $\quad$ C6 $=$ Student Activities $=1$

g. $\mathrm{C7}=\mathrm{RCS}:$ Research $=3$

h. $\mathrm{C} 8=\mathrm{RCS}$ : Community Services $=3$

i. $\quad$ C9 = RCS: Publication (Sinta Rating $)=3$

j. $\quad \mathrm{C} 10=$ Inovation $($ Number of Inovation $)=1$

\subsection{Manual Calculation}

In this manual calculation the writer uses dummy data as an example of how this method works. The data used are 5 pieces that are represented using letters only (do not use the name of the actual college as an alternative name). The data are as follows:

\section{TABLE I. Alternative DATA CALCULATION} MANUAL

\begin{tabular}{|c|c|c|c|c|c|c|c|c|c|c|c|}
\hline No & $\begin{array}{c}\text { Name } \\
\text { PT }\end{array}$ & C1 & C2 & C3 & C4 & C5 & C6 & C7 & C8 & C9 & C10 \\
\hline 1 & A & 32 & 2 & 70 & 11 & B & 0.33 & Madya & Memuaskan & 109 & 2 \\
\hline 2 & B & 30 & 5 & 102 & 14 & B & 0.92 & Utama & $\begin{array}{c}\text { Sangat } \\
\text { Bagus }\end{array}$ & 211 & 3 \\
\hline 3 & C & 24 & 3 & 43 & 7 & A & 1.3 & Mandiri & Unggul & 97 & 5 \\
\hline 4 & D & 16 & 6 & 98 & 13 & C & 2.2 & Binaan & Memuaskan & 102 & 3 \\
\hline 5 & E & 21 & 2 & 89 & 10 & B & 1.3 & Madya & Memuaskan & 189 & 2 \\
\hline
\end{tabular}

Next calculate the weight of each data:

TABLE II. WEIGHTING RESULTS MATRIX

\begin{tabular}{|c|c|c|c|c|c|c|c|c|c|c|c|}
\hline No & $\begin{array}{c}\text { Nama } \\
\text { PT }\end{array}$ & C1 & C2 & C3 & C4 & C5 & C6 & C7 & C8 & C9 & C10 \\
\hline 1 & A & 2 & 2 & 3 & 4 & 3 & 2 & 2 & 2 & 4 & 1 \\
\hline 2 & B & 2 & 2 & 3 & 4 & 3 & 2 & 3 & 3 & 4 & 1 \\
\hline 3 & C & 3 & 2 & 3 & 4 & 4 & 3 & 4 & 4 & 4 & 2 \\
\hline 4 & D & 4 & 2 & 3 & 4 & 2 & 3 & 1 & 2 & 4 & 1 \\
\hline 5 & E & 3 & 2 & 4 & 3 & 3 & 3 & 2 & 2 & 4 & 1 \\
\hline
\end{tabular}

The following is a normalization matrix calculation:

1. Alternative Names : A (A1)

$$
\begin{array}{rlrl}
A 1_{1} & =\frac{2-2}{4-2}=0 & A 1_{6} & =\frac{2-2}{3-2}=0 \\
A 1_{2} & =\frac{2-2}{2-2}=0 & A 1_{7} & =\frac{2-1}{4-1}=0.333 \\
A 1_{3} & =\frac{3-3}{4-3}=0 & A 1_{8} & =\frac{2-2}{4-2}=0 \\
A 1_{4} & =\frac{4-3}{4-3}=1 & A 1_{9} & =\frac{4-4}{4-4}=0
\end{array}
$$




$$
A 1_{5}=\frac{3-2}{4-2}=0.5 \quad A 1_{10}=\frac{1-1}{2-1}=0
$$

2. Alternative Names : B (A2)

$$
\begin{array}{rlrl}
A 2_{1} & =\frac{2-2}{4-2}=0 & A 2_{6} & =\frac{2-2}{3-2}=0 \\
A 2_{2} & =\frac{2-2}{2-2}=0 & A 2_{7} & =\frac{3-1}{4-1}=0.667 \\
A 2_{3} & =\frac{3-3}{4-3}=0 & A 2_{8} & =\frac{3-2}{4-2}=0.5 \\
A 2_{4} & =\frac{4-3}{4-3}=1 & A 2_{9} & =\frac{4-4}{4-4}=0 \\
A 2_{5} & =\frac{3-2}{4-2}=0.5 & A 2_{10} & =\frac{1-1}{2-1}=0
\end{array}
$$

3. Alternative Names : C (A3)

$$
\begin{array}{rlrl}
A 3_{1} & =\frac{3-2}{4-2}=0.5 & A 3_{6} & =\frac{3-2}{3-2}=1 \\
A 3_{2} & =\frac{2-2}{2-2}=0 & A 3_{7} & =\frac{4-1}{4-1}=1 \\
A 3_{3} & =\frac{3-3}{4-3}=0 & A 3_{8} & =\frac{4-2}{4-2}=1 \\
A 3_{4} & =\frac{4-3}{4-3}=1 & A 3_{9} & =\frac{4-4}{4-4}=0 \\
A 3_{5} & =\frac{4-2}{4-2}=1 & A 3_{10} & =\frac{2-1}{2-1}=1
\end{array}
$$

\begin{tabular}{|c|c|c|c|c|c|c|c|c|c|c|c|}
\hline $\begin{array}{l}\mathbf{N} \\
\mathbf{o}\end{array}$ & $\begin{array}{c}\text { Name } \\
\mathbf{P T}\end{array}$ & $\mathbf{C 1}$ & $\mathbf{C 2}$ & $\mathbf{C 3}$ & $\mathbf{C 4}$ & $\mathbf{C 5}$ & $\mathbf{C 6}$ & $\mathbf{C 7}$ & $\mathbf{C 8}$ & $\mathbf{C 9}$ & $\mathbf{C 1 0}$ \\
\hline 1 & $\mathrm{~A}$ & 0 & 0 & 0 & 1 & 0.5 & 0 & 0.333 & 0 & 0 & 0 \\
\hline 2 & $\mathrm{~B}$ & 0 & 0 & 0 & 1 & 0.5 & 0 & 0.667 & 0.5 & 0 & 0 \\
\hline 3 & $\mathrm{C}$ & 0.5 & 0 & 0 & 1 & 1 & 1 & 1 & 1 & 0 & 1 \\
\hline 4 & $\mathrm{D}$ & 1 & 0 & 0 & 1 & 0 & 1 & 0 & 0 & 0 & 0 \\
\hline 5 & $\mathrm{E}$ & 0.5 & 0 & 1 & 0 & 0.5 & 1 & 0.333 & 0 & 0 & 0 \\
\hline
\end{tabular}

The next step will be to multiply between the normalization matrix and the preference weights. The following is the calculation of the matrix multiplication:

$\mathrm{A} 1=(3 * 0)+(3 * 0)+(3 * 0)+(3 * 1)+(4 * 0.5)+(1 * 0)+(3 * 0.333)$ $+(3 * 0)+(3 * 0)+(1 * 0)=5.999$

$\mathrm{A} 2=(3 * 0)+(3 * 0)+(3 * 0)+(3 * 1)+(4 * 0.5)+(1 * 0)+(3 * 0.667)$

\begin{tabular}{|c|c|c|c|c|c|}
\hline \multirow[b]{2}{*}{$\begin{array}{l}\mathbf{N} \\
\mathbf{o}\end{array}$} & \multirow[b]{2}{*}{$\begin{array}{c}\text { Pergurua } \\
\text { n Tinggi }\end{array}$} & \multicolumn{4}{|c|}{ SDM } \\
\hline & & $\begin{array}{c}\text { Persentase } \\
\text { Dosen } \\
\text { Mahasiswa } \\
(1: \ldots) \\
\end{array}$ & $\begin{array}{c}\text { Dosen } \\
\text { S1 }\end{array}$ & $\begin{array}{l}\text { Dose } \\
\text { n S2 }\end{array}$ & $\begin{array}{c}\text { Dosen } \\
\text { S3 }\end{array}$ \\
\hline 1 & A & 50.8 & 1 & 201 & 32 \\
\hline 2 & B & 42 & 18 & 450 & 70 \\
\hline 3 & $\mathrm{C}$ & 15 & 8 & 293 & 41 \\
\hline 4 & $\mathrm{D}$ & 17.7 & 14 & 166 & 7 \\
\hline 5 & $\mathrm{E}$ & 33.4 & 9 & 148 & 13 \\
\hline 6 & F & 64.6 & 4 & 86 & 14 \\
\hline
\end{tabular}
$+(3 * 0.5)+(3 * 0)+(1 * 0)=8.501$

$\mathrm{A} 3=(3 * 0.5)+(3 * 0)+(3 * 0)+(3 * 1)+(4 * 1)+(1 * 1)+(3 * 0.1)+$ $(3 * 1)+(3 * 0)+(1 * 1)=13.8$

$\mathrm{A} 4=\left(3^{*} 1\right)+\left(3^{*} 0\right)+\left(3^{*} 0\right)+\left(3^{*} 1\right)+\left(4^{*} 0\right)+\left(1^{*} 1\right)+\left(3^{*} 0\right)+\left(3^{*} 0\right)$ $+(3 * 0)+(1 * 0)=7$

$\mathrm{A} 5=(3 * 0.5)+(3 * 0)+(3 * 1)+(3 * 0)+(4 * 0.5)+(1 * 1)+(3 * 0.333)$ $+(3 * 0)+(3 * 0)+(1 * 0)=8.499$

From the results of calculations performed using the MAUT method, campus ratings are obtained from the dummy data as follows:

\section{TABLE IV. TABLE STYLES}

\begin{tabular}{|c|c|c|}
\hline Campus & Score & Rank \\
\hline C & 13.8 & $\mathbf{1}$ \\
\hline B & 8.501 & $\mathbf{2}$ \\
\hline E & 8.499 & $\mathbf{3}$ \\
\hline D & 7 & $\mathbf{4}$ \\
\hline A & 5.999 & $\mathbf{5}$ \\
\hline
\end{tabular}

\section{RESUlt AND DisCUSSION}

In this section the author will describe the results obtained from the application of the MAUT method to the processed data. The data will later be used as criteria in the calculation process. Data obtained and processed are as follows:

TABLE V. DATA OBTAINED AND WILl BE PROCESSED
5. Alternative Names: E (A5)

$$
\begin{array}{rlrl}
A 5_{1} & =\frac{3-2}{4-2}=0.5 & A 5_{6} & =\frac{3-2}{3-2}=1 \\
A 5_{2} & =\frac{2-2}{2-2}=0 & A 5_{7} & =\frac{2-1}{4-1}=0.333 \\
A 5_{3} & =\frac{4-3}{4-3}=1 & A 5_{8} & =\frac{2-2}{4-2}=0 \\
A 5_{4} & =\frac{3-3}{4-3}=0 & A 5_{9} & =\frac{4-4}{4-4}=0 \\
A 5_{5} & =\frac{3-2}{4-2}=0.5 & A 5_{10} & =\frac{1-1}{2-1}=0
\end{array}
$$

Matrix normalization results:

\section{TABLE III. MATRIX NORMALITATION}




\begin{tabular}{|c|c|c|c|c|c|}
7 & $\mathrm{G}$ & 45 & 10 & 289 & 32 \\
\hline 8 & $\mathrm{H}$ & 37.7 & 46 & 265 & 50 \\
\hline 9 & $\mathrm{I}$ & 34 & 2 & 223 & 25 \\
\hline & $\mathrm{J}$ & 1. & 3 & 57
\end{tabular}$\quad$\begin{tabular}{|r|r|r|r|}
8 \\
\hline 10 & $\mathrm{I}$ & $\mathrm{J}$ & 0 \\
\hline 10 & $\mathrm{~J}$ & 0 \\
\hline
\end{tabular}

Based on the data obtained, it can be seen the weighting results of all criteria from alternative data A1 to A10 (representation of campus data A, B, C, D, E, F, G, H, I and J) as follows:

\section{TABle VI. WeIGHTING All CRITERIA REsults}

\begin{tabular}{|r|c|r|r|r|r|r|r|r|r|r|r|}
\hline No & $\begin{array}{c}\text { Data } \\
\text { Alternatif }\end{array}$ & C1 & C2 & C3 & C4 & C5 & C6 & C7 & C8 & C9 & C10 \\
\hline 1 & A1 & 1 & 3 & 4 & 4 & 3 & 2 & 2 & 2 & 4 & 1 \\
\hline 2 & A2 & 1 & 2 & 4 & 4 & 4 & 2 & 3 & 3 & 4 & 1 \\
\hline 3 & A3 & 4 & 2 & 4 & 4 & 3 & 1 & 2 & 2 & 4 & 1 \\
\hline 4 & A4 & 4 & 2 & 4 & 2 & 2 & 2 & 2 & 2 & 3 & 1 \\
\hline 5 & A5 & 2 & 2 & 4 & 3 & 3 & 2 & 1 & 2 & 3 & 1 \\
\hline 6 & A6 & 1 & 2 & 4 & 4 & 2 & 2 & 2 & 2 & 3 & 1 \\
\hline 7 & A7 & 1 & 2 & 4 & 3 & 3 & 2 & 2 & 2 & 4 & 1 \\
\hline 8 & A8 & 1 & 1 & 3 & 4 & 3 & 1 & 1 & 1 & 4 & 1 \\
\hline 9 & A9 & 2 & 3 & 4 & 4 & 3 & 2 & 2 & 2 & 4 & 1 \\
\hline 10 & A10 & 1 & 2 & 4 & 1 & 1 & 1 & 1 & 1 & 1 & 1 \\
\hline
\end{tabular}

After obtaining weighting matrix data from alternative data possessed the next step is to carry out the normalization process with the values $x_{i}^{-}$and $x_{i}^{+}$ for each criterion as follows:

\section{TABLE VII. WORST AND BEST WEIGHT OF THE $\mathrm{X}$} CRITERIA

\begin{tabular}{|r|c|r|r|}
\hline No & Kriteria & \multicolumn{1}{|c|}{$\boldsymbol{x}_{\boldsymbol{i}}^{-}$} & \multicolumn{1}{|c|}{$\boldsymbol{x}_{\boldsymbol{i}}^{+}$} \\
\hline 1 & $\mathrm{C} 1$ & 1 & 4 \\
\hline 2 & $\mathrm{C} 2$ & 1 & 3 \\
\hline 3 & $\mathrm{C} 3$ & 3 & 4 \\
\hline 4 & $\mathrm{C} 4$ & 1 & 4 \\
\hline 5 & $\mathrm{C} 5$ & 1 & 5 \\
\hline 6 & $\mathrm{C} 6$ & 1 & 2 \\
\hline 7 & $\mathrm{C} 7$ & 1 & 3 \\
\hline 8 & $\mathrm{C} 8$ & 1 & 3 \\
\hline 9 & $\mathrm{C} 9$ & 1 & 4 \\
\hline 10 & $\mathrm{C} 10$ & 1 & 1 \\
\hline
\end{tabular}

So we get the normalization matrix as follows:

TABLE VIII. NORMALIZATION MATRIX RESULTS

\begin{tabular}{|r|c|r|r|r|r|r|r|r|r|r|r|}
\hline No & $\begin{array}{c}\text { Data } \\
\text { Alternatif }\end{array}$ & \multicolumn{1}{c|}{ C1 } & C2 & C3 & C4 & C5 & C6 & C7 & C8 & C9 & C10 \\
\hline 1 & A1 & 0 & 1 & 1 & 1 & 0.667 & 1 & 0.5 & 0.5 & 1 & 0 \\
\hline 2 & A2 & 0 & 0.5 & 1 & 1 & 1 & 1 & 1 & 1 & 1 & 0 \\
\hline 3 & A3 & 1 & 0.5 & 1 & 1 & 0.667 & 0 & 0.5 & 0.5 & 1 & 0 \\
\hline
\end{tabular}




\begin{tabular}{|r|r|r|r|r|r|r|r|r|r|r|r|}
\hline 4 & $\mathrm{~A} 4$ & 1 & 0.5 & 1 & 0.333 & 0.333 & 1 & 0.5 & 0.5 & 0.667 & 0 \\
\hline 5 & $\mathrm{~A} 5$ & 0.333 & 0.5 & 1 & 0.667 & 0.667 & 1 & 0 & 0.5 & 0.667 & 0 \\
\hline 6 & $\mathrm{~A} 6$ & 0 & 0.5 & 1 & 1 & 0.333 & 1 & 0.5 & 0.5 & 0.667 & 0 \\
\hline 7 & $\mathrm{~A} 7$ & 0 & 0.5 & 1 & 0.667 & 0.667 & 1 & 0.5 & 0.5 & 1 & 0 \\
\hline 8 & $\mathrm{~A} 8$ & 0 & 0 & 0 & 1 & 0.667 & 0 & 0 & 0 & 1 & 0 \\
\hline 9 & $\mathrm{~A} 9$ & 0.333 & 1 & 1 & 1 & 0.667 & 1 & 0.5 & 0.5 & 1 & 0 \\
\hline 10 & $\mathrm{~A} 10$ & 0 & 0.5 & 1 & 0 & 0 & 0 & 0 & 0 & 0 & 0 \\
\hline
\end{tabular}

The next step is to calculate the normalization matrix multiplication with the preference weights:

\section{TABLE IX. NORMALIZATION MATRIX RESULTS}

\begin{tabular}{|r|c|c|}
\hline \multicolumn{1}{|c|}{ No } & Data Alternatif & Result \\
\hline 1 & A1 & 18.66667 \\
\hline 2 & A2 & 21.5 \\
\hline 3 & A3 & 19.16667 \\
\hline 4 & A4 & 15.83333 \\
\hline 5 & A5 & 14.66667 \\
\hline 6 & A6 & 14.83333 \\
\hline 7 & A $~$ & 16.16667 \\
\hline 8 & A $~$ & 8.666667 \\
\hline 9 & A9 & 19.66667 \\
\hline 10 & A10 & 4.5 \\
\hline
\end{tabular}

From the results obtained from data processing and calculations using the Multi Attribute Utility Theory (MAUT) method, the results of the ranking of the best tertiary institutions in the city of Medan can be displayed:

\section{TABLE X. RESULT RANKING USING MAUT}

\begin{tabular}{|r|c|c|c|}
\hline No & Campus & Score & Ranking \\
\hline 1 & B & 21.5 & 1 \\
\hline 2 & I & 19.66667 & 2 \\
\hline 3 & C & 19.16667 & 3 \\
\hline 4 & A & 18.66667 & 4 \\
\hline 5 & G & 16.16667 & 5 \\
\hline 6 & D & 15.83333 & 6 \\
\hline 7 & F & 14.83333 & 7 \\
\hline 8 & E & 14.66667 & 8 \\
\hline 9 & H & 8.666667 & 9 \\
\hline 10 & J & 4.5 & 10 \\
\hline
\end{tabular}

From the results shown in table 4.17 it can be seen that University B was ranked 1 (first) with a value of 21.5 according to calculations using the MAUT method. Followed by University of I with a value of 19.6667 which was ranked 2, University $C$ with a value of 19.1667 which was ranked 3, A with a value of 18.6667 which was ranked 4, and University G with a value of 161667 which was ranked 5 .

Then University D with a value of 15.8333 which was ranked rank 6 , University $F$ with a value of 14.8333 which was ranked 7 th, University $\mathrm{E}$ with a value of 14.6667 which was ranked 8th, University $\mathrm{H}$ with a value of 8.6667 which was ranked 9th, and University $\mathrm{J}$ with a value of 4.5 which was ranked 10 th.

From the results provided by the calculation of the MAUT method there are certainly many shortcomings in terms of data that the author may not receive is too accurate and there are still many criteria that the authors and the team did not enter because of time and access limitations in collecting all the data that should have been used.

However, the application of this method can help, at least the institution where the writer is located, in seeing his ranking in the field and can be a benchmark of anything that can be changed or improved if you want to rank up and get the maximum value.

\section{Conclusion AND Suggestion}

The conclusions that can be drawn from the results of the research carried out are as follows:

1. With the implementation of the Multi Attribute Utility Theory method in the case of ranking the campus in the city of Medan able to provide optimal results based on predetermined criteria and weightings.

2. In this method the use of weighting criteria, weighting preferences, and alternative data is very influential in the calculation and results provided.

3. To be used as the main reference in ranking the campus in the city of Medan still cannot. But it can be used as an additional reference and can only be used by the internal campus of Universitas Harapan Medan due to the limited data available.

\section{ACKNOWLEDGMENT}

Thank you to the research institute and journal publication at the Harapan University of Medan, Mr. Ruswan Nurmadi, who facilitated the authors in the research conducted so that the publication of this publication. And thanks also to the Chancellor of Universitas Harapan Medan, Prof. Prof. Dr. Ritha F. Dalimunthe and thanks Dr. Rahmat Widia Sembiring who helped in the completion of the research the author did. And thanks to all those who cannot be mentioned one by one. 


\section{REFERENCES}

Badrul, M., Rusdiansyah, R., \& Budihartanti, C. (2019). Application of Simple Additive Weighting Method for Determination of Toddler Nutrition Status. SinkOn, 4(1), 19-24.

Fajirwan, D., Arhami, M., \& Amalia, I. (2018). Sistem Pendukung Keputusan Penerimaan Bantuan Renovasi Rumah Dhuafa Menggunakan Metode Multi Attribute Utility Theory. Jurnal Infomedia, 3(2), 49-57.

Imandasari, T., \& Windarto, A. P. (2017). Sistem Pendukung Keputusan dalam Merekomendasikan Unit Terbaik di PDAM Tirta Lihou Menggunakan Metode Promethee. Jurnal Teknologi Dan Sistem Komputer, 5(4), 159.

https://doi.org/10.14710/jtsiskom.5.4.2017.159 $-165$

Kemenristekdikti. (2018). Kemenristekdikti Umumkan Peringkat 100 Besar Perguruan Tinggi Indonesia Non Vokasi Tahun 2018. Retrieved February 12, 2019, from 17 Agustus 2018 website: https://ristekdikti.go.id/kabar/kemenristekdikti -umumkan-peringkat-100-besar-perguruantinggi-indonesia-non-vokasi-tahun-2018/

Latif, L. A., Jamil, M., \& Abbas, S. H. (2018).
SISTEM PENDUKUNG KEPUTUSAN TEORI DAN IMPLEMENTASI. Sleman: Deepublish.

Puspitasari, N. B., Rumita, R., \& Pratama, G. Y. (2013). Pemilihan Strategi Bisnis dengan menggunakan QSPM (Quantitive Strategic Planning Matrix) dan Model MAUT (Multi Atribute Utility Theory) (Studi Kasus pada Sentra Gerabah Kasongan, Bantul, Yogyakarta). Universitas Diponegoro, VIII(3), 171-180.

Sadewo, M. G., Windarto, A. P., \& Hartama, D. (2017). PENERAPAN DATAMINING PADA POPULASI DAGING AYAM RAS PEDAGING DI INDONESIA BERDASARKAN PROVINSI MENGGUNAKAN K-MEANS CLUSTERING. InfoTekJar (Jurnal Nasional Informatika Dan Teknologi Jaringan), 2(1), 60-67.

https://doi.org/10.30743/infotekjar.v2i1.164

Satria, E., Atina, N., Simbolon, M. E., \& Windarto, A. P. (2018). Spk: Algoritma Multi-Attribute Utility Theory ( Maut) Padadestinasi Tujuan Wisata Lokal Di Kota Sidamanik. 3(2), 168172. 